\title{
Penerapan Metode Diskusi Kelompok Kecil dalam Model Pembelajaran Think-Talk-Write sebagai Upaya Meningkatkan Prestasi Belajar Bahasa Inggris
}

\author{
Ni Made Perawati $1^{*}$ \\ ${ }^{1}$ SMK Negeri 1 Klungkung, Indonesia
}

\section{A R T I C L E I N F O}

Article history:

Received 20 October 2020

Received in revised form

30 November 2020

Accepted 10 January 2021

Available online 01

February 2021

\section{Kata Kunci:}

Model Pembelajaran

Think-Talk-Write, Diskusi

Kelompok Kecil Prestasi

Belajar Bahasa Inggris

Keywords:

Think-Talk-Write Learning

Model, Small Group

Discussion of English

Learning Achievement

\begin{abstract}
A B S T R A K
Rendahnya hasil belajar siswa dalam pembelajaran Bahasa inggris disebabkan oleh model pembelajaran yang dilakukan masih bersifat konvensiaonal. Tujuan penelitian adalah untuk mengetahui efektivitas model pembelajaran Think Talk Write dengan diskusi kelompok kecil dapat meningkatkan prestasi belajar siswa. jenis penelitian ini adalah penelitian tindakan kelas. Subjek penelitian ini adalah sebanyak 36 siswa. Metode pengumpulan datanya adalah tes prestasi belajar. Metode analisis datanya adalah deskriptif baik untuk data kualitatif maupun untuk data kuantitatif. Hasil yang diperoleh dari penelitian ini adalah model pembelajaran Think-Talk-Write dapat meningkatkan prestasi belajar siswa. Ini terbukti dari hasil yang diperoleh pada awalnya mencapai nilai rata-rata 66,11 , pada siklus I mencapai nilai rata-rata 72,36 dan pada siklus II mencapai nilai rata-rata 78,75. Jadi, model pembelajaran ThinkTalk-Write dapat meningkatkan prestasi belajar Bahasa Inggris siswa kelas $\mathrm{X}$.
\end{abstract}

\section{A B S T R A K}

The low learning outcomes of students in learning English are caused by the conventional learning model. The research objective was to determine the effectiveness of the Think Talk Write learning model with small group discussions to improve student learning achievement. This type of research is classroom action research. The subjects of this study were 36 students. The data collection method is a learning achievement test. The data analysis method is descriptive both for qualitative data and for quantitative data. The results obtained from this study are that the Think-Talk-Write learning model can improve student learning achievement. This is evident from the results obtained at first reaching an average value of 66.11, in the first cycle it reached an average value of 72.36 and in the second cycle, it reached an average value of 78.75 . So, the Think-Talk-Write learning model can improve the English learning achievement of class $X$ students.

\section{Pendahuluan}

Mata pelajaran Bahasa Inggris berdasarkan kurikulum berbasis kompetensi adalah program untuk mengembangkan pengetahuan, keterampilan berbahasa, dan sikap positif terhadap Bahasa Inggris. Menyimak merupakan salah satu bagian dari mata pelajaran Bahasa Inggris dalam kurikulum berbasis kompetensi (Chang et al., 2011; Wang \& Treffers-Daller, 2017). Kurikulum berbasis kompetensi meliputi aspek kemampuan berbahasa. Aspek keterampilan berbahasa meliputi keterampilan mendengarkan, berbicara, membaca dan menulis yang berhubungan dengan ragam sastra (Göbel \& Helmke, 2010; Yang et al., 2013; Zhang, 2016). Dalam pembelajaran bahasa, aspek keterampilan berbahasa dan keterampilan bersastra harus dilakukan secara seimbang.

Teknik pembelajaran bahasa Inggris yang bervariasi tentunya dapat menarik minat belajar peserta didik. Hal ini merupakan tantangan bagi para guru bahasa Inggris. Perlu inovasi yang terus 
berkembang dari para guru agar peserta didik dapat terlibat secara aktif dalam proses pembelajaran. Untuk mencapai kemampuan bahasa Inggris yang optimal, diperlukan instruktur bahasa yang profesional agar menghasilkan peserta didik yang berkualitas. Selain itu, penguasaan materi dan praktek harus diberikan dengan porsi yang seimbang. Namun, untuk mewujudkan kelas bahasa yang ideal bukanlah hal yang mudah. Selain memiliki pengasaan materi yang cukup, seorang pengajar bahasa seharusnya mengetahui tingkat penguasaan bahasa masing-masing peserta didik. Jika semua kondisi disamaratakan, akan terasa sulit untuk mencapai tujuan pembelajaran yang diharapkan (Megawati, 2016). Dalam proses pembelajaran bahasa Inggris, seorang siswa tentu pernah mengalami suatu hambatan dalam belajar. Hambatan tersebut dapat menimbulkan kurang maksimalnya hasil belajar siswa (Megawati, 2016; Surjono \& Susila, 2013).

Berdasarkan hasil observasi kondisi yang sama juga terjadi di SMK Negeri 1 Klungkung Berdasarkan hasil observasi yang peneliti lakukan, dapat diketahui bahwa pembelajaran Bahasa Inggris di kelas X AKKL 1 masih dilakukan secara konvensional. Metode yang digunakan masih dengan metode ceramah, yaitu siswa hanya mendengarkan pada saat guru sedang menjelaskan, proses pembelajaran hanya berpusat pada guru. Akibatnya prestasi belajar siswa hanya mencapai nilai rata-rata 66,11. Menghadapi kondisi yang sangat mengkhawatirkan, maka perlu adanya upaya perbaikan dalam proses pembelajaran agar dapat meningkatkan keterampilan proses dalam pembelajaran Bahasa Inggris yaitu khususnya pada kemampuan analisis dalam memahami materi Bahasa Inggris. Salah satu alternatif yang digunakan yaitu dengan menggunakan model pembelajaran Think-Talk-Write.

Model pembelajaran Think Talk Write (TTW) adalah model pembelajaran yang dapat menumbuh kembangkan kemampuan pemahaman dan komunikasi siswa. Think-Talk-Write merupakan pembelajaran kooperatif yang kegiatan pembelajarannya melalui kegiatan berpikir (think), berbicara/berdiskusi, bertukar pendapat (talk) serta menuliskan hasil diskusi (write) agar tujuan pembelajaran dan kompetensi yang diharapkan dapat tercapai (Angriani et al., 2016; Trisnani, 2020). Alur model Think-Talk-Write dimulai dari keterlibatan siswa dalam berpikir atau berdialog dengan dirinya sendiri setelah proses membaca, selanjutnya berbicara dan membagi ide dengan temannya kemudian menulis hasil diskusi. Model ini lebih efektif jika dilakukan dalam kelompok heterogen dengan 3-5 siswa. Dalam kelompok ini semua siswa diminta membaca, membuat catatan kecil, menjelaskan, mendengar dan membagi ide bersama teman kemudian mengungkapkannya melalui tulisan. Melalui model pembelajaran Think Talk Write (TTW) dengan diskusi kelompok kecil ini perhatian siswa akan terpusat pada materi, karena siswa mengalami atau terlibat langsung dalam proses pembelajaran. Siswa dapat mengutarakan gagasan, serta berpendapat selama proses diskusi dalam pembelajaran

Beberapa penelitian mengenai model pembelajaran TTW telah dilakukan seperti penelitian yang dilakukan oleh (Trisnani, 2020) yang menyatakan bahwa adanya peningkatan kemampuan komunikasi matematika siswa dari kategori sangat rendah dan rendah meningkat menjadi kategori sedang, tinggi dan sangat tinggi, maka dapat disimpulakan bahwa penrapan model pembelajaran kooperatif tipe think talk write dapat meningkatkan kemampuan komunikasi matematika siswa. Kemudian penelitian yang dilakukan oleh (Angriani et al., 2016) menyatakan bahwa pembelajaran kooperatif Think-Talk-Write dapat meningkatkan kemampuan pemecahan masalah matematika. Penelitian lain juga dilakukan oleh (Parmika et al., 2018) yang menyatakan bahwa terdapat pengaruh signifikan model pembelajaran TTW berbasis penilaian portofolio terhadap hasil belajar Bahasa Indonesia siswa kelas V SD di Gugus IV Kecamatan Banjar Kabupaten Buleleng Tahun Pelajaran 2017/2018.

Penelitian mengenai diskusi kelompok kecil dilakukan oleh (Ernawati, 2020) yang menyatakan bahwa metode diskusi dapat meningkatkan hasil belajar siswa dalam menyelesaikan soal penjumlahan dan pengurangan. Kemudian penelitian yang dilakukan oleh (Safitri et al., 2014) yang menyatakan bahwa kegiatan yang dilakukan oleh guru bahasa Indonesia di kelas VII SMP Laboratorium Undiksha Singaraja pada saat membimbing diskusi kelompok kecil ada enam kegiatan. Keenam kegiatan itu antara lain : (1) memusatkan perhatian, (2) memperjelas masalah, (3) menganalisis pandangan siswa, (4) meningkatkan partisipasi siswa terhadap kelompok, (5) menyebarkan kesempatan berpartisipasi, dan (6) menutup diskusi. Penelitian lain juga dilakukan oleh (Andika et al., 2014) menyatakan bahwa model pembelajaran inkuiri melalui diskusi kelompok kecil berpengaruh positif terhadap hasil belajar sains siswa kelas V SD N Gugus 6 Batubulan. Kemudian penelitian lain juga dilakukan oleh (Miasari, 2018) menyatakan bahwa penerapan metode diskusi kelompok kecil dalam pelaksanaan proses pembelajaran mampu meningkatkan prestasi belajar matematika siswa kelas VI semester II SD Negeri 2 Peguyangan tahun pelajaran 2016/2017. Tujuan penelitian ini adalah untuk menganalisis model pembelajaran Think Talk Write dengan diskusi kelompok kecil untuk meningkatkan prestasi belajar siswa. 


\section{Metode}

Penelitian ini tergolong Penelitian Tindakan Kelas (Classroom Action Research) (Sugiyono, 2016). Penelitian Tindakan Kelas (PTK) merupakan penelitian yang dilakukan oleh guru di dalam kelasnya melalui refleksi diri, dengan tujuan untuk memperbaiki kinerja sebagai guru, sehingga Kejenuhan belajar siswa menjadi berkurang. PTK sebagai suatu bentuk penelitian yang bersifat reflektif dengan melakukan tindakan-tindakan tertentu agar dapat memperbaiki dan atau meningkatkan praktek-praktek pembelajaran di dalam kelas secara lebih profesional.

Untuk penelitian ini penulis memilih rancangan penelitian tindakan yang disampaikan Depdiknas seperti terlihat pada Gambar 1.

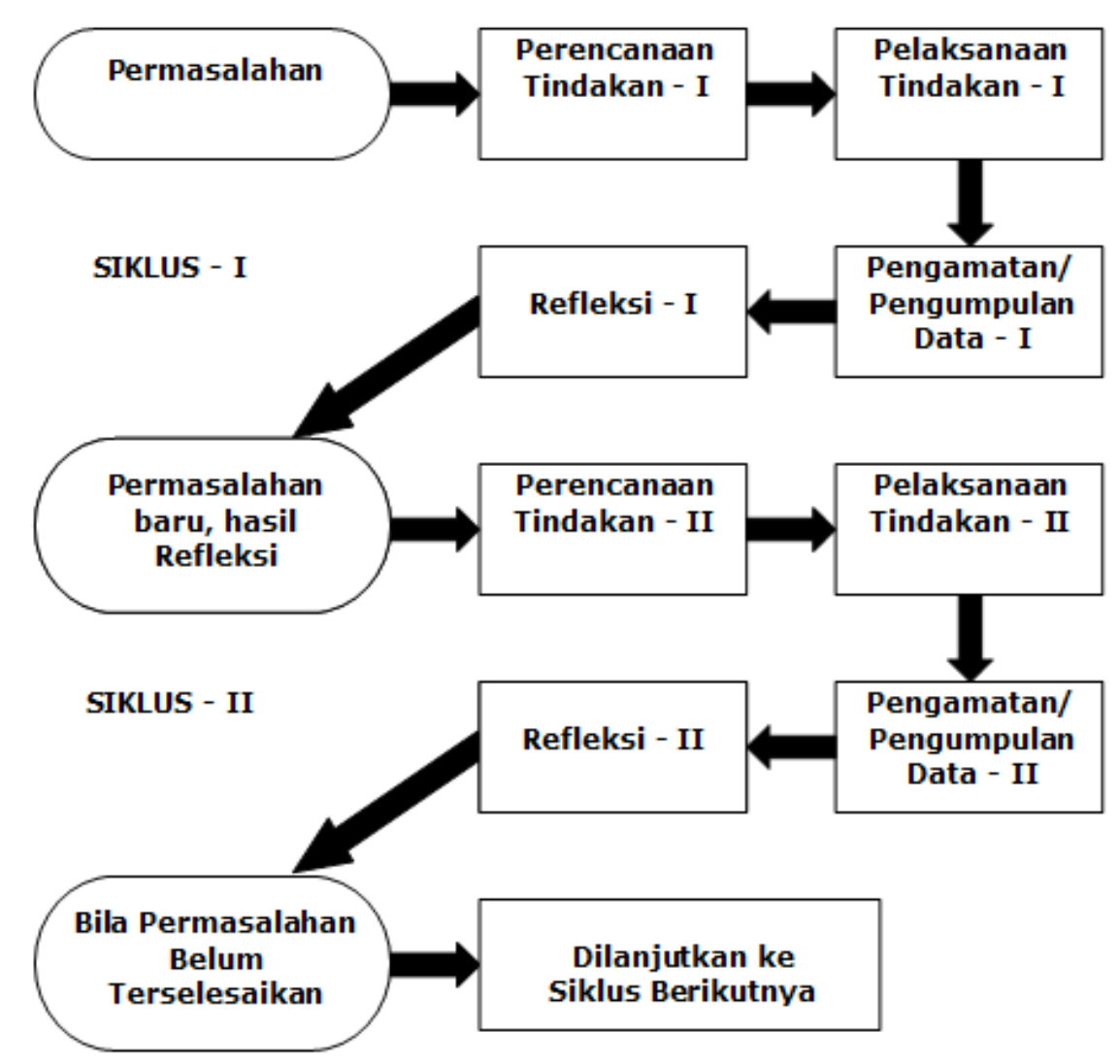

Gambar 1. Rancangan Penelitian Depdiknas (2011:12)

Dimulai dengan melihat adanya masalah di lapangan. Dengan adanya masalah di lapangan maka peneliti mulai membuat perencanaan I dan selanjutnya melaksanakannya, mengamati atau mengumpulkan data, melakukan refleksi I. Setelah ada permasalahan baru hasil refleksi lalu dibuat perencanaan siklus II, dilanjutnya dengan pelaksanaannya, diamati atau diobservasi dan direfleksi dan apabila permasalahan belum selesai dilanjutkan dengan siklus berikutnya. Pengumpulan data dalam penelitian ini menggunakan tes prestasi belajar. Tes prestasi belajar berupa tes soal isian maupaun esay. Setelah data dalam penelitian ini terkumpul selanjutnya dilakukan analisis data. Dalam menganalisis data digunakan teknik analisis statistik deskriptif kuantitatif. Indikator keberhasilan penelitian yang diusulkan dalam penelitian ini pada siklus I dan II mencapai nilai rata-rata 75,00 dengan ketuntasan belajar 85\%. dengan KKM yang ditetapkan untuk mata pelarajan Bahasa Inggris pada SMK Negeri 1 Klungkung adalah 73

\section{Hasil dan Pembahasan}

Perubahan dalam kemampuan dan keterampilan serta tingkah laku anak menuju arah yang semakin membaik menunjukkan bahwa ketuntasan belajar Bahasa Inggris yang dipersyaratkan sudah dapat dicapai dengan baik oleh anak sebagai akibat proses belajar sehari-hari yang dilaksanakan baik di dalam kelas maupun di luar kelas. Sehubungan dengan hasil belajar ini, untuk SMK Negeri 1 Klungkung 
masih membutuhkan bimbingan guru dikarenakan banyak diantara mereka yang masih berada di bawah kriteria ketuntasan minimal yang dipersyaratkan.

Untuk mengatasi masalah tersebut, guru sebagai peneliti mengupayakan jalan pemecahan dengan menerapkan model pembelajaran Think-Talk-Write. Dengan model tersebut merupakan suatu cara mengajar untuk menanamkan kebiasaan-kebiasaan tertentu dimana anak melaksanakan kegiatankegiatan latihan secara berulang-ulang, agar anak memiliki ketangkasan atau keterampilan yang lebih tinggi dari apa yang dipelajari sebelumnya. Semakin sering pengulangan dilakukan akan semakin tinggi tingkat keterampilan peserta didik menguasai materi yang diajarkan. Dengan cara tersebut menurut peneliti merupakan suatu cara yang dapat memberikan percepatan dalam proses pencapaian tujuan pembelajaran karena dapat menciptakan suasana belajar yang kondusif dan menyenangkan bagi anak. Dengan menggunakan cara ini tanpa disadari anak bahwa dalam proses bermainnya ada pembelajaran yang sedang dijalani dengan berulang.

Hasil siklus awal diperolehan nilai rata rata kelas prestasi belajar Bahasa Inggris masih sangat rendah, yaitu dengan perolehan skor nilai secara klasikal yaitu 2380 dan rata rata kelas 66,11 dimana siswa yang mencapai persentase ketuntasan belajar 33,33\%, dan yang tidak mencapai ketuntasan adalah $66,66 \%$, dengan tuntutan KKM untuk Bahasa Inggris adalah dengan nilai 75 . Rendahnya hasil yang diperoleh siswa pada awal pembelajaran disebabkan peneliti belum menggunakan model pembelajaran dan RPP yang digunakan masih bersifak konvensional.

Hasil yang diperoleh masih jauh dari indikator yang diharapkan maka dari itu peneliti sangat perlu melakukan perbaikan pembelajaran pada siklus I dengan menggunakan model pembelajaran ThinkTalk-Write. Pada siklus I sudah diupayakan untuk perbaikan pembelajaran untuk meningkatkan hasil belajar dengan menggunakan model pembelajaran Think-Talk-Write. Peneliti telah giat melakukan kegiatan yang susuai dengan kebenaran teori yang ada sehingga peneliti memperoleh hasil yang lebih baik dari proses awal, yaitu dengan rata-rata nilai 72,36 dari jumlah nilai secara klasikal 2605 seluruh siswa SMK Negeri 1 Klungkung, dan prosentase ketuntasan belajarnya adalah 69,44\%, yang tidak tuntas adalah $30,55 \%$.

Hasil ini belum maksimal, karena belum mecapai indikator keberhasilan penelitian yang mencanangkan dengan minimal prosentase ketuntasan belajar 85\%. Dengan tindakan yang sangat maksimal dan pelaksanaan yang betul-betul mengikuti kebenaran teori sesuai dengan model pembelajaran Think-Talk-Write dalam pembelajaran Bahasa Inggris SMK Negeri 1 Klungkung, dimana hasil yang diperoleh pada siklus II ini ternyata Hasil belajar Bahasa Inggris meningkat secara signifikan dengan nilai rata-rata 78,75 dan ketuntasan belajarnya adalah 100\%. Dari keseluruhan jumlah siswa yaitu 36 orang siswa 36 orang siswa telah mampu melampaui nilai KKM yaitu 75.

Model pembelajaran Think-Talk-Write (TTW) adalah model pembelajaran yang dapat menumbuh kembangkan kemampuan pemahaman dan komunikasi siswa. Think-Talk-Write merupakan pembelajaran kooperatif yang kegiatan pembelajarannya melalui kegiatan berpikir (think), berbicara/berdiskusi, bertukar pendapat (talk) serta menuliskan hasil diskusi (write) agar tujuan pembelajaran dan kompetensi yang diharapkan dapat tercapai (Angriani et al., 2016; Trisnani, 2020). Alur model Think-Talk-Write dimulai dari keterlibatan siswa dalam berpikir atau berdialog dengan dirinya sendiri setelah proses membaca, selanjutnya berbicara dan membagi ide dengan temannya kemudian menulis hasil diskusi. Model ini lebih efektif jika dilakukan dalam kelompok heterogen dengan 3-5 siswa. Dalam kelompok ini semua siswa diminta membaca, membuat catatan kecil, menjelaskan, mendengar dan membagi ide bersama teman kemudian mengungkapkannya melalui tulisan.

Metode diskusi kelompok kecil dalam model pembelajaran Think Talk Write berjalan dengan baik yaitu dapat dilihat dari cara guru membimbing diskusi kelompok kecil yang sudah sesuai dengan komponen-komponen yang terdapat dalam keterampilan membimbing. Guru juga tampak menjadi fasilitator dan motivator dalam proses diskusi kelompok kecil. Pada saat membimbing diskusi kelompok guru harus mampu mengarahkan dan mengontrol siswa agar sejalan dengan tujuan pembelajaran. Guru telah melakukan hal- hal yang dilakukan ketika membimbing dikusi kelompok kecil mulai dari memusatkan perhatian siswa, memperjelas masalah, menganalisis pandangan siswa, meningkatkan partisipasi siswa terhadap kelompok, meyebarkan kesempatan berpartisipasi, dan menutup diskusi. Hal tersebut dapat membuat pembelajaran menjadi efektif sehingga berdampak pada hasil belajar bahasa Inggris siswa. Melalui model pembelajaran Think Talk Write (TTW) dengan diskusi kelompok kecil ini perhatian siswa akan terpusat pada materi, karena siswa mengalami atau terlibat langsung dalam proses pembelajaran. Siswa dapat mengutarakan gagasan, serta berpendapat selama proses diskusi dalam pembelajaran. Proses pembelajaran seperti ini akan mampu meningkatkan aktivitas siswa lebih- lebih dalam pembelajaran sains yang sangat menuntut keterlibatan siswa dalam pembelajaran, dan berujung pada optimalnya hasil belajar, karena proses belajar akan sangat berpengaruh besar terhadap hasil belajar (Miasari, 2018; Segara \& Hermansyah, 2019). Sudjana (dalam Andika et al., 2014) menyatakan 
bahwa teknik pembentukan kelompok kecil bertujuan untuk membina keakraban dan keterbukaan dalam memilih teman-teman berkelompok. Teknik ini dilakukan untuk membentuk kelompok- kelompok kecil yang jumlah anggotanya terbatas antara 4-5 orang secara heterogen.

Hasil penelitian ini sejalan dengan beberapa penelitian mengenai model pembelajaran TTW telah dilakukan seperti penelitian yang dilakukan oleh (Trisnani, 2020) yang menyatakan bahwa adanya peningkatan kemampuan komunikasi matematika siswa dari kategori sangat rendah dan rendah meningkat menjadi kategori sedang, tinggi dan sangat tinggi, maka dapat disimpulakan bahwa penrapan model pembelajaran kooperatif tipe think talk write dapat meningkatkan kemampuan komunikasi matematika siswa. Kemudian penelitian yang dilakukan oleh (Angriani et al., 2016) menyatakan bahwa pembelajaran kooperatif Think-Talk-Write dapat meningkatkan kemampuan pemecahan masalah matematika. Penelitian lain juga dilakukan oleh (Parmika et al., 2018) yang menyatakan bahwa terdapat pengaruh signifikan model pembelajaran TTW berbasis penilaian portofolio terhadap hasil belajar Bahasa Indonesia siswa kelas V SD di Gugus IV Kecamatan Banjar Kabupaten Buleleng Tahun Pelajaran $2017 / 2018$.

Hasil penelitian ini juga sejalan dengan penelitian yang dilakukan oleh (Ernawati, 2020) yang menyatakan bahwa metode diskusi dapat meningkatkan hasil belajar siswa dalam menyelesaikan soal penjumlahan dan pengurangan. Kemudian penelitian yang dilakukan oleh (Safitri et al., 2014) yang menyatakan bahwa kegiatan yang dilakukan oleh guru bahasa Indonesia di kelas VII SMP Laboratorium Undiksha Singaraja pada saat membimbing diskusi kelompok kecil ada enam kegiatan. Keenam kegiatan itu antara lain : (1) memusatkan perhatian, (2) memperjelas masalah, (3) menganalisis pandangan siswa, (4) meningkatkan partisipasi siswa terhadap kelompok, (5) menyebarkan kesempatan berpartisipasi, dan (6) menutup diskusi. Penelitian lain juga dilakukan oleh (Andika et al., 2014) menyatakan bahwa model pembelajaran inkuiri melalui diskusi kelompok kecil berpengaruh positif terhadap hasil belajar sains siswa kelas V SD N Gugus 6 Batubulan. Kemudian penelitian lain juga dilakukan oleh (Miasari, 2018) menyatakan bahwa penerapan metode diskusi kelompok kecil dalam pelaksanaan proses pembelajaran mampu meningkatkan prestasi belajar matematika siswa kelas VI semester II SD Negeri 2 Peguyangan tahun pelajaran 2016/2017.

\section{Simpulan dan Saran}

Berdasarkan pemaparan di atas, dapat disimpulkan bahwa penerapan metode diskusi kelompok kecil dalam model pembelajaran Think-Talk-Write secara efektif dapat meningkatkan prestasi belajar bahasa Inggris siswa kelas X AKKL 1 SMK Negeri 1 Klungkung semester I tahun pelajaran 2018/2019.

\section{Daftar Rujukan}

Andika, I. M. P., Suadnyana, I. N., \& Zulaikha, S. (2014). Pengaruh Model Pembelajaran Inkuiri Melalui Diskusi Kelompok Kecil Terhadap Hasil Belajar Sains Siswa Kelas V SD Gugus 6 Batubulan. MIMBAR PGSD Undiksha, https://ejournal.undiksha.ac.id/index.php/JJPGSD/article/view/1874.

Angriani, A. D., Bernard, B., Nur, R., \& Nurjawahirah, N. (2016). Meningkatkan Kemampuan Pemecahan Masalah Melalui Pembelajaran Kooperatif Think-Talk-Write Pada Peserta Didik Kelas Viii1 MTsN MODEL MAKASSAR. MaPan: Jurnal Matematika Dan Pembelajaran, 4(1), 11-28. https://doi.org/10.24252/mapan.2016v4n1a2.

Chang, C. C., Tseng, K. H., \& Tseng, J. S. (2011). Is single or dual channel with different English proficiencies better for English listening comprehension, cognitive load and attitude in ubiquitous learning environment? Computers and Education, 57(4), 2313-2321. https://doi.org/10.1016/j.compedu.2011.06.006.

Ernawati, E. (2020). Penggunaan Metode Diskusi Untuk Meningkatkan Hasil Belajar Siswa Dalam Menyelesaikan Penjumlahan Dan Pengurangan. Jurnal Educatio FKIP UNMA, 6(2), 125-131. https://doi.org/https://doi.org/10.31949/educatio.v6i1.285.

Göbel, K., \& Helmke, A. (2010). Intercultural learning in English as foreign language instruction: The importance of teachers' intercultural experience and the usefulness of precise instructional directives. Teaching and Teacher Education, 26(8), 1571-1582. https://doi.org/10.1016/j.tate.2010.05.008.

Megawati, F. (2016). Kesulitan Mahasiswa Dalam Mencapai Pembelajaran Bahasa Inggris Secara Efektif. Jurnal Pedagogia, 5(2). http://ojs.umsida.ac.id/index.php/pedagogia/article/view/246/227. 
Miasari, N. M. (2018). Peningkatan Prestasi Belajar Matematika Dengan Penggunaan Metode Diskusi Kelompok Kecil Pada Siswa Kelas Vi Semester Ii Sd Negeri 2 Peguyangan Tahun Pelajaran 2016/2017. Adi Widya: Jurnal Pendidikan Dasar, http://www.ejournal.ihdn.ac.id/index.php/AW/article/view/885.

Parmika, D. M., Suarni, N. K., \& Parmiti, D. P. (2018). Pengaruh Model Pembelajaran Think Talk Write (TTW) Berbasis Penilaian Portofolio terhadap Hasil Belajar Bahasa Indonesia. Jurnal Pedaagogi Dan Pembelajaran, 1(3). https://doi.org/10.23887/ijee.v2i3.15967.

Safitri, M., Gunatama, G., \& Darmayanti, I. A. M. (2014). Keterampilan Membimbing Diskusi Kelompok Kecil oleh Guru Bahasa Indonesia di Kelas VII SMP Laboratorium Undiksha. Jurnal Pendidikan Bahasa Dan Sastra Undiksha, https://ejournal.undiksha.ac.id/index.php/JJPBS/article/view/3288/2716.

2(1).

Segara, N. B., \& Hermansyah, H. (2019). Online Peer Assessment Untuk Mengembangkan Keterampilan Presentasi Oral Diskusi Kelompok Kecil pada Pembelajaran IPS. Jurnal Pendidikan Ilmu Sosial, 28(2), 139-151. https://ejournal.upi.edu/index.php/jpis/article/view/20191/pdf.

Sugiyono. (2016). Metode Penelitian Kualitatif, Kuantitatif, dan R\&D. Alfabeta.

Surjono, H. D., \& Susila, H. R. (2013). Pengembangan multimedia pembelajaran bahasa inggris untuk SMK. Jurnal Pendidikan Vokasi, 3(1), 45-52. https://doi.org/10.21831/jpv.v3i1.1576.

Trisnani, N. (2020). Peningkatan Kemampuan Komunikasi Matematika Siswa SD Kelas V Melalui Tipe Pembelajaran Think Talk Write (TTW). Scholaria: Jurnal Pendidikan Dan Kebudayaan, 10(2), 92102. https://doi.org/10.24246/j.js.2020.v10.i2.p92-102.

Wang, Y., \& Treffers-Daller, J. (2017). Explaining listening comprehension among L2 learners of English: The contribution of general language proficiency, vocabulary knowledge and metacognitive awareness. System, 65, 139-150. https://doi.org/10.1016/j.system.2016.12.013.

Yang, Y. T. C., Chuang, Y. C., Li, L. Y., \& Tseng, S. S. (2013). A blended learning environment for individualized English listening and speaking integrating critical thinking. Computers and Education, 63, 285-305. https://doi.org/10.1016/j.compedu.2012.12.012.

Zhang, L. J. (2016). Reflections on the pedagogical imports of western practices for professionalizing ESL/EFL writing and writing-teacher education. Australian Review of Applied Linguistics, 39(3), 203-232. https://doi.org/10.1075/aral.39.3.01zha. 